\title{
CNC GÉP SZERSZÁMPARAMÉTER KEZELÉSI RENDSZERÉNEK VIZSGÁLATA
}

\author{
Komondi Márk ${ }^{a}$, Andó Mátyás ${ }^{b^{*}}$ \\ a ELTE, Informatikai Kar, Savaria Müszaki Intézet, Duális gépészmérnöki BSc, 4. évf. \\ ${ }^{b}$ ELTE, Informatikai Kar, Savaria Müszaki Intézet, egyetemi docens
}

\begin{abstract}
ABSZTRAKT
A szerszámkezelési rendszer vizsgálata során az adatbázis alapú szerszámkezeléssel foglalkoztunk, azon belül meghatároztuk a lehetséges szerszámfelügyeleti módszereket. A szerszámkorrekciók esetén egy fejlettségi sorrendet állítottunk fel, majd elemeztük azokat. Megállapítottuk, hogy az automatikus munkadarab bemérés alapján végzett szerszámkorrekció a leghatékonyabb módszer a selejt gyártás elkerüléséhez a relatívan rövid mérési idô miatt. Ráadásul a felügyelet nélküli megmunkálás is megvalósítható, ha a testvérszerszám-stratégiát is alkalmazzuk. Ebben az esetben az is elôny, hogy a lapka élettartamát maximálisan kihasználhatjuk, akár egyedi gyártás esetén is. A megmunkálási folyamatok optimalizálásához használt virtuális környezetben is megismételtük a szerszámgépeken gyakorlatban elvégzett teszteket, azonosítva a különbségeket (munkadarab számlálás).
\end{abstract}

Kulcsszavak: CNC, kopás, szerszámfelügyelet, testvérszerszám-stratégia, CPS, virtuális környezet

\section{Bevezetés}

Az elsô CNC szerszámgépek megjelenése az 1970-es évek közepére tehetô, megjelenésük lehetôvé tette a rugalmas gyártórendszerek létrehozásának lehetőségét, amely napjainkban elengedhetetlen, ha a vállalat versenyképes szeretne maradni. A rugalmas gyártórendszerek kialakításának lehetősége az informatika fejlődésének köszönhető. A szerszámgépek hálózatba kötésével már megoldható, hogy egy gépen ellenôrizzük a szerszámkészletet, vagy végrehajtsunk egy szerszámbemérést, mindezt távoli vezérlést alkalmazva [1].

A CNC gépeken végzett méréseket többféle módon lehet csoportosítani. Beszélhetünk folyamat közbeni mérésekrôl, melyet a megmunkálási folyamat közben végez a gép, azonban ez forgácsolás esetén a hútővíz és az egyéb szennyeződések miatt nem minden esetben ad megfelelő pontosságot (például köszörülésnél átmérő mérés). A forgácsolási folyamatoknál is alkalmazhatunk olyan mérést, mely megszakítja a folyamatot, ilyen például a munkadarab beméréssel végzett szerszámkorrekció, amely egy adott megmunkálóciklus végén kerül elvégzésre. Ezen felül megkülönböztetünk folyamat előtt vagy után végzett méréseket, mely nem a megmunkáló program része, ilyen például a beépített szerszámbemérôvel történô szerszámbemérés felszerszámozásnál [2].

A szerszámok használatuk során kopnak, ezért élettartamuk véges. A megfelelő felügyeletük elvégezhetô a vezérlő által is, ezáltal egy fontos lépést tehetünk az ember nélküli felügyelettel történő gyártás irányába. A szerszám kopása azonban azt a kérdést is felveti, hogy mikor érdemes azt lecserélni, meddig tudunk gazdaságosan selejt előállítása nélkül gyártani. A megfelelő feltételek teljesülése esetén a vezérlő ezt a feladatot is el tudja látni [3, 4].

(C) ELTE, Informatikai Kar, Savaria Múszaki Intézet, 2020

*Kapcsolattartó: am@inf.elte.hu

https://doi.org/10.37775/EIS.2020.1.5 


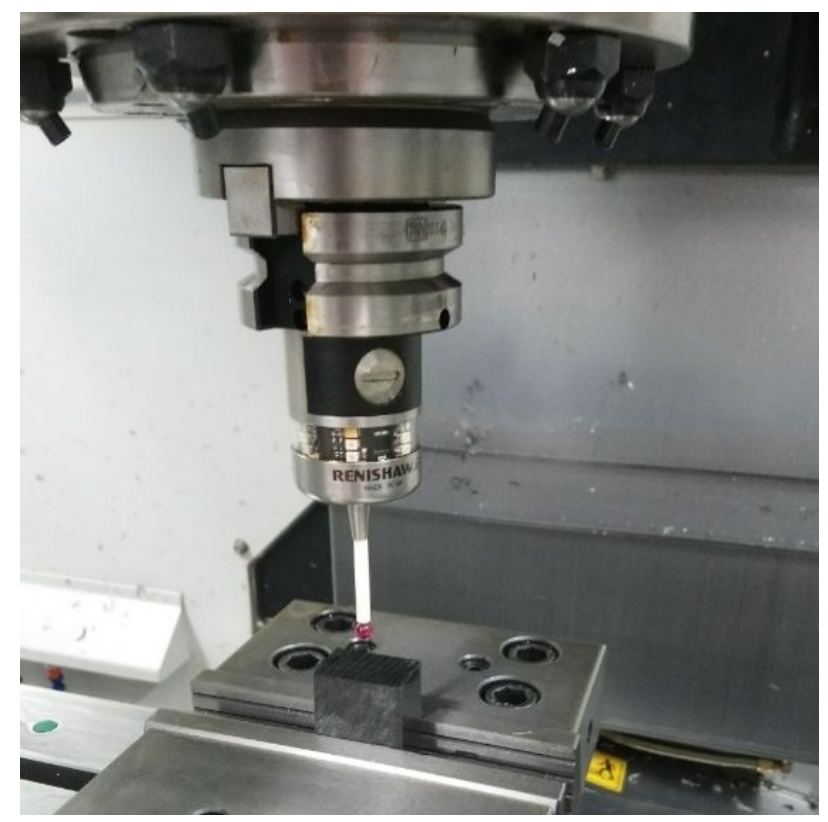

1. ábra: Mérôtapintó múködés közben

Adatbázis alapú megközelítés miatt, a szerszámtárolóban kezdeményezhetjük a szerszámok szưrését, rendezését valamilyen szempontok szerint (például: szerszámtípusonként rendezés, zárolt szerszámok kiszúrése), valamint kereshetünk a szerszámokra, vagy üres tárhelyekre is, amelyre az új szerszám behelyezhetô $[4,5]$.

Célunk a szerszámok adatbázisának kezelésére fordított idő csökkentése, emellett a szerszámkorrekciózási módszerek között egy fejlettségi sorrend felállítása. Megvizsgáltuk, hogy melyik módszer esetén lehetséges a felügyelet nélküli gyártás hatékony megvalósítása. Az emberi beavatkozás nélkül gyártáshoz hozzátartozik a szerszámok felügyelete és a testvérszerszám-stratégia alkalmazása is, ezért ezekkel is foglalkozunk ebben a cikkben.

\section{Módszer}

A bevezetésben említett módszerek vizsgálatát Akira-Seiki SL25 esztergagépen és Akira-Seiki V2.5XP marógépen végeztük el. Mindkét gép a Sinumerik 828D vezérlójével van felszerelve, emellett a teszteket a SinuTrain szimulátorban is lefuttattuk. A szerszámgépek beépített szerszámbemérôvel voltak felszerelve, valamint mindkettő rendelkezett a munkadarab beméréshez szükséges mérôtapintóval (1. ábra).

Az egyes szerszámokról a vezérlő tárolja a megmunkáláshoz szükséges adatokat, tulajdonságokat. Ezek a tulajdonságok a vezérlóben paraméter formájában vannak eltárolva. A vizsgálatok elvégzésére készítettünk egy programot melyekkel könnyen kinyerhetók a szerszámspecifikus paraméterek. A Gkódban írt program a vizsgálat szempontjából fontos információkat kikéri a vezérlóból és betölti az R-paraméterek közé (2. ábra). A módszer a munkadarab beméréssel végzett szerszámkorrekció és a szerszámkorrekció adatainak vizsgálatakor is használható.

A szerszámkorrekciók esetén többféle fejlettségi szintet különböztetünk meg (3. ábra). Ritkább esetben előfordulhat, hogy nem végeznek szerszámkorrekciót, de inkább az a jellemzô, hogy bizonyos idôközönként ellenőrzik a sorozatgyártott terméket és szükség esetén történik a korrekció (3. ábra, 1. lépés). Előfordulhat az is, hogy a munkadarab adott méretének mérési eredményei alapján változtatják a szerszám korrekciós értékét, így változtatva a szerszám pályáját, ezáltal pedig a munkadarab adott méretét is (3. ábra, 2. lépés). Ennél fejlettebb módszer, bár ugyanaz a kategória, amikor 


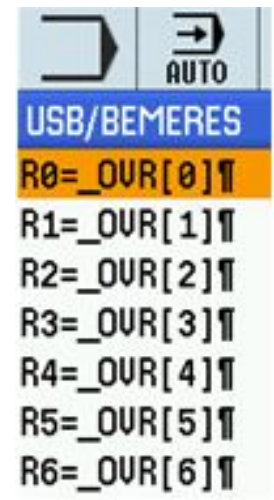

2. ábra: Szerszámparaméterekből R-paraméterek készítése

közvetlenül mérjük be a szerszám vágóélét egy szerszámbemérôvel (3. ábra, 3. lépés), ami már automatizálható. A legfejlettebb módszer a szerszámok bemérésére (szerszámkorrekció) a gépen belül elvégzett munkadarab bemérés (3. ábra, 4. lépés) alapján. Ez egy automatikus folyamat, a megfelelő program mellett szükséges hozzá egy mérôtapintó, amellyel elvégezhető a munkadarab bemérése.

A vizsgálataink során a felügyelet nélküli gyártás elérése a célunk, ezért csak a 3. és 4. szintú megoldással foglalkozunk a továbbiakban. A tesztek során két esetet vizsgáltunk meg, ezekhez megmunkáló programot készítettünk, hogy felmérjük a szerszámgépek viselkedését. Az egyik programot úgy készítettük el, hogy a szerszámot kétszer is be kelljen cserélnie a gépnek, de az elsố megmunkálás közben a szerszám zárolásra kerül. Míg a második program esetében azt vizsgáltuk, hogy a vezérlő hogyan reagál, ha egy program ismételt indításakor érzékeli, hogy az elôzô futtatáskor a szerszám zárolásra került.

\section{Szerszámkorrekciók és felügyelet elemzése}

A szerszámok korrekciójára azok megmunkálás során fellépő kopása miatt van szükség. Ezzel elérhetô, hogy az adott szerszámmal tưrés tartományán belül gyárthatók le a munkadarabok. Azonban a szerszám egy bizonyos kopottság után nem használható tovább, mivel nem eredményezne megfelelő felületi érdességet. További probléma, hogy a forgácsoló erô megnő, ami nagyobb deformációhoz vezet, valamint a hőmérséklet is emelkedni fog. A megmunkálás nemcsak veszítene a hatékonyságából, de a múködési körülmények is folyamatosan változnának (lényegesen csökkenne az üzembiztonság).

A szerszámkorrekció történhet úgy, hogy a szerszámot közvetlenül bemérjük. Ezáltal a szerszám korrekciós értéke szabályozott lesz, a munkadarab mérete, pedig vezérelt. A bemérés történhet a

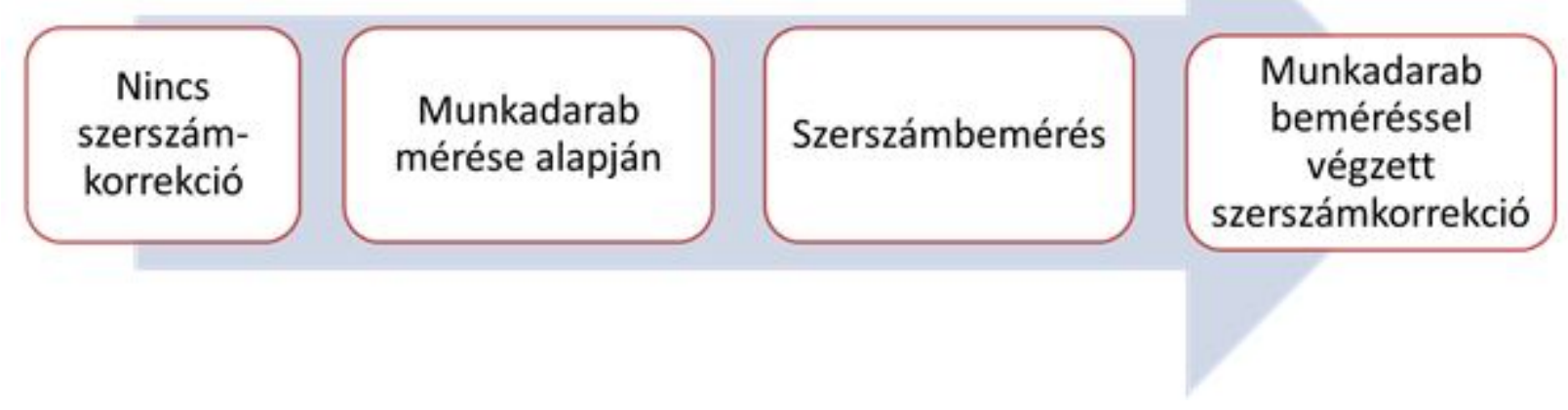

3. ábra: Szerszámkorrekciózás szintjei 
gépen kívüli bemérôn (gyártósoron történô gyártás esetén), vagy a gépbe szerelt bemérôn is. A szerszámkorrekciózás fejlettebb rendszere az automatikus munkadarab méréssel végzett szerszámkorrekció. Az automatikus szerszámkorrekciót a szerszámgép megfelelô beállítás esetén a megmunkált munkadarab bemérésével elvégzi. Ebben az esetben a munkadarab mérete szabályozott, míg a szerszám korrekciós értékét a munkadarab méreteiból és a szerszámpálya programozott értékéból számítja ki a vezérlő. Az elv jól felhasználható a gyártórendszerben a felügyelet nélküli gyártás eléréséhez. Fontos megjegyezni, hogy ebben az esetben a kopás és a szerszám deformációja összesítve lesz mérve - mely kifejezetten előnyös, ha a kopással arányosan a szerszámdeformáció is változik.

A Sinumerik vezérlők esetén lehetőség van szerszámfelügyeleti módszerek beállítására. Amely történhet legyártott munkadarab darabszámmal, a szerszám megmunkálási idótartamának számolásával, valamint a szerszámkopás alapján (függetlenül attól, hogy az adat honnan származik) [4]. A legfejletlenebb szerszámfelügyeleti módszer a darabszámmal történő megfigyelés. Ebben az esetben a megmunkálás kezdetekor a vezérlô levon egyet a még megmunkálható darabok számából. Ha a megmunkálható darabok száma eléri a nullát, akkor a vezérlő zárolja a szerszámot. A módszerhez minden munkadarab esetén meg kell határozni, hogy mennyi gyártható belóle az adott szerszámmal. A vezérlő nem veszi figyelembe, hogy az adott szerszám mennyit dolgozik egy adott megmunkáló program lefutása során. A szerszámhoz beállítható elö-figyelmeztetési határ is. Ezt egy bizonyos darabszám után éri el, amely közel van élettartama végéhez, és egy figyelmeztetést jelent, hogy a szerszám hamarosan zárolásra kerül. A szerszám zárolása után a becserélt szerszámmal az adott megmunkáló program még lefut, de egy új program indítása esetén a vezérló a szerszámot már nem cseréli be. Ez a módszer nem használható egyedi gyártásnál vagy kis sorozatoknál.

A megmunkálási idô alapján történô megfigyelés eggyel fejlettebb módszer a szerszámfelügyeletre, mivel ez számolja az adott szerszám megmunkálásban töltött idejét. Minden szerszám esetén be lehet állítani egy rá jellemzô értéket, mely független a megmunkálási programtól (alkatrésztől). A problémát ebben az esetben az jelenti, hogy eltérő forgácsolási paraméterek esetén a szerszám nem egyformán van igénybe véve, így eltérő mértékben kopik az egyes megmunkáló ciklusok során. Az elő-figyelmeztetési határ beállítása ebben az esetben is lehetséges. A szerszám zárolása pedig a megmunkálási ideje lejárta után történik meg. Tömegtermelésnél jól használható, de segítséget ad kisebb sorozatoknál, esetleg optimalizált paraméter kitöltésú programozásnál is (adatbázis alapján történik a paraméter kitöltés, így adott megmunkálási körülmények között ugyanazokat a forgácsolási paramétereket használjuk).

Ahhoz, hogy a szerszámfelügyeleti módszerek megfelelően múködjenek számos tesztre van szükség az adott szerszámokkal, mire megtaláljuk azt a megmunkálási idôt vagy darabszámot, amely után a szerszám tényleg elkopottnak minôsül, így elkerülve azt, hogy idő eloott legyenek kicserélve a szerszámok. A szerszámfelügyeleti módszerek közül a szerszámkopás közvetett vagy közvetlen mérése a legmegbízhatóbb megoldás, mivel ez figyelembe veszi a lapka eltéréseit is (például gyártási hibák, bevonatvastagság változása...). A szerszám kopásának közvetett mérése esetén a munkadarab méretéból kiszámítva írjuk be a szerszám kopását, míg közvetlen módszer esetén a szerszámot magát mérjük be. Ilyenkor a szerszámkopástárolóba a szerszám kopásának nagyságát kell beírni, amit levon a megadott maximális kopásértékból a vezérló, így a továbbiakban a még hátralevő kopást fogja kijelezni. Amint eléri a maximális kopásértéket a szerszám zárolásra kerül. Ez azt jelenti, hogy a szerszám kopási folyamatától függetlenül azonosítani tudjuk mikor éri el a múködési határt. Ezzel a módszerrel elkerülhető, hogy idő előtt cserélünk lapkát, vagyis azokat múködési tartományukban maximálisan kihasználhatjuk. Kiválóan használható tömegtermelésnél, kis és nagy sorozatok esetén, de akár egyedi gyártásnál is.

Az ember nélküli szerszámfelügyeletben a szerszámfelügyeleteknek kiemelt szerepük van, mivel segítségükkel a megfelelő feltételek teljesülése esetén a szerszámok zárolhatók. Egy szerszám a záro- 
lás után nem használható tovább, így fenntartva a gyártás folyamatos minôségét. Ha egy szerszám zárolásra került, ki kell tölteni a gépból cserélni a lapkát, beállítani vagy bemérni és visszatölteni a CNC gépbe. Ez egy hosszadalmas folyamat, amely során nem folytatható megmunkálás. Erre kínál megoldást a testvérszerszám-stratégia. Ennek segítségével a szerszám zárolása esetén becserélhetô annak testvérszerszáma, amellyel elvégezheti az adott megmunkálást. Így a termelés nem áll meg, nincs kieső idő a termelésben. Azonban ehhez szükségesek a megfelelő beállítások, hogy a vezérlő testvérszerszámként kezelje az adott szerszámot. A szerszámok beszerelésekor kettô, vagy több szerszámot is be kell mérni, így elég a gépet egyszer felszerszámozni például a múszak elején, és nem kell megállítani minden egyes szerszámcserélésekor.

\section{Eredmények}

A testvérszerszám-stratégia megfelelő múködését a fent említett Akira-Seiki gyártmányú CNC maró és esztergagépeken vizsgáltuk meg, valamint szimulált környezetben is elvégeztük a tesztelést. A szimulátoros tesztelés a szerszámgépek növekvő leterheltsége miatt egyre fontosabbá válik. Így a gép folyamatosan gyárthat, míg virtuális megfelelőjén futtatják a teszteket. A testvérszerszám-stratégia és a szerszámfelügyeletek vizsgálatát a SinuTrain nevû szoftverben futtattuk le, így hasonlítva össze a valós megmunkálógép viselkedését a szimulált gépi környezet viselkedésével.

Korszerú környezetben, felügyelet nélküli gyártásnál nem használható a véletlenszerú szerszámkorrekció. Ezért csak automatikus mérés eredménye alapján érdemes meghatározni a lapka kopását. Szerszámok adatbázis alapú kezelése a modern gyártórendszerekben a szerszámok száma miatt elkerülhetetlen. A szerszámtároló kezelési megoldások segítségével csökkenthetô a szerszámok keresésével töltött idô, valamint szû́rhetôk a szerszámok adott szempontok szerint. Itt kiemelnénk a zárolt, valamint az elő-figyelmeztetési határt elért szerszámokra történő szűrés jelentôségét, ugyanis ezzel kiválasztható az összes olyan szerszám, amellyel zárolása miatt már nem lehetséges a megmunkálás, vagy amelyek rövid határidőn belül zárolásra fognak kerülni (elérte az elő-figyelmeztetési határt). Ezek cserélése szükséges, amely így jelentôsen gyorsabban megoldható, mintha végig kellene nézni a teljes szerszámtárat. Ez a megoldás a szerszámmenedzsmentet nagyban segíti és növeli annak hatékonyságát.

A szerszámok korrekciós értékének meghatározására a leghatékonyabb megoldás az automatikus munkadarab beméréssel végzett szerszámkorrekció. A funkció a Sinumerik vezérlóben a megmunkáló programba egy ciklusként illeszthetô be. Emiatt a szerszámgép a program futtatása során automatikusan végzi el a kiválasztott mérést. A szerszámgépen lehetôség van a munkadarab tưréshatárait is megadni, így a vezérlő hibaüzenetet tud küldeni, ha selejt került legyártásra. A funkció segítségével a gyártásközi mérések száma lecsökkenthetô, mert a CNC gép a szerszámot is korrekciózza, tehát jelentősen csökkenthető a méréssel töltött idő.

A szerszámfelügyeleti módszerek hatására zárolt szerszámok tovább már nem használhatók. A testvérszerszám-stratégia alkalmazásához az eredeti szerszámmal azonos tulajdonságú szerszámot kell beszerelni a megmunkáló gépbe, valamint azt fel is kell venni a szerszámtárba. Az elnevezésnél fontos, hogy karakterre pontosan ugyanazt a nevet kapja, mint az eredeti szerszám, mivel a vezérlő csak így fogja testvérszerszámként kezelni. A megmunkáló programok futtatása alapján mindkét esetben elmondható (programon belül kétszer illetve egyszer behívott szerszám esetén), hogy testvérszerszám nélkül a vezérlő hibaüzenettel leállt és nem folytatta a megmunkálást. Ebben az esetben a kopott szerszámot ki kell cserélni és újat szerelni be helyette. Ha a szerszámnak van testvérszerszáma, akkor a megmunkálás nem áll le hibaüzenettel, hanem a vezérlő becseréli a megfelelô szerszámot, és folytatja, vagy éppen elkezdi a megmunkálást az adott szerszámmal.

Vizsgálataink kiterjedtek a SinuTrain szoftver által kínált lehetőségekre is. Ezek során azt mértük 
fel, hogy a valós gép és a program azonosan viselkedik-e a szerszámfelügyeletek és a testvérszerszámstratégia alkalmazásakor. Ebben az esetben elmondható, hogy a testvérszerszám-stratégia és a felügyeleti módszerek hasonlóan múködtek, mint a valós szerszámgép esetén, kivéve a darabszámmal történő megfigyelést, amelynél a megmunkált darabok száma nem vonódott le a legyártható darabok számából.

\section{5. Összefoglalás}

A szerszámkezelési rendszer vizsgálata alapján megállapítottuk, hogy az adatbázis alapú szerszámkezelés segíti a hatékony munkavégzést például a szerszámkarbantartás kapcsán. Rámutattunk, hogy a munkadarab alapú, az idő alapú és a kopás alapú szerszámfelügyelet közül utóbbi a megfelelő, ha a rendszert optimálisan akarjuk üzemeltetni. A szerszámkorrekció elemzése kapcsán megállapítottuk, hogy a felügyelet nélküli gyártáshoz a munkadarab-bemérés alapú szerszámkorrekció hatékonyabb, hiszen a gyártási ciklusidőt nem növeli (korszerú rendszereknél már eleve minôsíteni kell a darabot). Az automatikus szerszámkorrekcióval a testvérszerszám stratégia megfelelően alkalmazható felügyelet nélküli gyártás eléréséhez. A megmunkálási folyamatok optimalizálását költséghatékonyabb virtuális környezetben folytatni, fóként a kiesố gépidô jelenti a nagy költséget. A tesztek alapján megállapítottuk, hogy a SinuTrain szimulációs környezete csak nagyon kevés eltérést tartalmazott a valós vezérlőhöz képest (például a darabszám figyelés).

\section{Köszönetnyilvánítás}

Az ED_18-1-2019-0030 szerződésszámú projekt (Alkalmazásiterület-specifikus nagy megbízhatóságú informatikai megoldások tématerület) a Nemzeti Kutatási Fejlesztési és Innovációs Alapból biztosított támogatással, a Tématerületi kiválósági program támogatásával valósult meg.

\section{Irodalomjegyzék}

[1] Zsidai L., Gépgyártástechnológia, Gyártórendszerek és elemeik, Szent István Egyetem, Gödöllő, 2015.

[2] L. Zhan-Qiang, P. K. Venuvinod, V.A. Ostafiev, On-machine measurement of workpieces with the cutting tool, Integrated Manufacturing Systems 9(3), 1998, pp. 168-172 CrossRef

[3] P. Waydande, N. Ambhore, S. Chinchanikar, A Review on Tool Wear Monitoring System, Journal of Mechanical Engineering and Automation 6(5A), 2016, pp. 49-53

[4] Siemens, Sinumerik 840D sl / 828D Esztergálás Kezelési kézikönyv 03/2013

[5] Siemens, Sinumerik 840D sl / 828D Alapok, Programozási kézikönyv 03/2013 